\title{
Do Institutionalists and post-Keynesians share a common approach to Modern Monetary Theory (MMT) ?*
}

\author{
Reynold F. Nesiba \\ Department of Economics, Augustana College, Sioux Falls, SD, USA
}

\begin{abstract}
Are Institutional and post-Keynesian economists converging on a shared approach to understanding Modern Monetary Theory (MMT)? The literature suggests growing recognition that post-Keynesians and Institutionalists share a common intellectual history, conceptual frameworks, and overlapping professional memberships. For this reason, PostKeynesian Institutionalism (PKI) has emerged as a unifying approach to heterodox economics. In this review of the Modern Monetary Theory (MMT) literature, I explore the degree to which this PKI convergence extends, or fails to extend, to the historical, theoretical, and policy issues surrounding MMT. The point of this paper is to delineate where scholars from these traditions agree, where they specifically disagree, and to explore whether or how these disagreements may be ameliorated with respect to MMT.
\end{abstract}

Keywords: Chartalism, Institutional economics, Modern Monetary Theory, monetary circuit theory, neo-Chartalism, post-Keynesian economics, Post-Keynesian Institutionalism

JEL codes: $B 25, B 52, E 12, E 32, E 50, E 52, E 62, E 64$

\section{INTRODUCTION}

Are Institutional and post-Keynesian economists converging on a shared approach to Modern Monetary Theory (MMT) - a specific way of understanding money, debt, and macroeconomic policy? There appears to be strong evidence and a growing body of scholarship that suggests an emerging heterodox consensus in the form of Post-Keynesian Institutionalism (PKI). Charles Whalen's 2011 edited volume, Financial Instability and Economic Security after the Great Recession, is a series of ten chapters - half of them authored or co-authored by Whalen - that outlines the intellectual foundations of PKI and its application to the American economy and the global economic system. These themes are revisited in his paper that appears in this volume. Whalen makes the case

* Earlier versions of this paper were presented at the University of Missouri-Kansas City's Economics Department's Money Seminar on Friday 2 March 2012 and at the 33rd annual Association for Institutional Thought (AFIT) meetings in conjunction with the Western Social Science Association's 54th annual conference in Houston, Texas on 11-14 April 2012. The author thanks Mat Forstater, Stephanie Kelton, John Henry, Anne Mayhew, Scott McConnell, Marc Lavoie and Mario Seccareccia for constructive criticism and assistance on earlier drafts of this paper. None of them is responsible for any remaining errors and shortcomings. This project benefitted from a sabbatical leave from Augustana College and the financial support of the Augustana Research and Artists Fund. 
three main ways. First, he shows (2011: 3) that a variety of Institutionalists and postKeynesians have written about this synthesis and made it clear that they feel comfortable in both schools of thought. Second, he demonstrates that the ideas of these two groups - particularly those of Commons and Keynes - shared a common history and approach. Thus, their purported differences were not so large as some assert. Third and finally, the rest of Whalen's book makes it abundantly clear that core theoretical notions of chronological time, ${ }^{1}$ fundamental uncertainty, expectations (or what Commons talked about as futurity), and the role of money are shared among post-Keynesians and Institutionalists and can be productively applied to the American economy and the global economic system. These theoretical notions are also in sharp contrast with mainstream theorists.

At first glance, it appears that Whalen has answered the question posed at the beginning of this paper in the affirmative. In a general sense, post-Keynesians and Institutionalists do appear to be converging on a shared approach to talking and arguing about money, debt, and monetary theory. However, depending on how we define MMT and how deeply we dig into the details of the literature, we start to see that, despite growing attention even in the mainstream press and a number of blogs, there are unresolved issues as theorists across and within schools of thought disagree. This is to be expected in any relatively new research program. ${ }^{2}$

The point of this paper is to delineate where in the academic literature Institutionalists, post-Keynesians and/or PKIs specifically agree, where they disagree, and to explore whether or how these disagreements can be improved or resolved with respect to MMT. The hope is that by clearing defining the main points of the theory and the controversies spawned in the literature, we can more easily identify urgent areas of future research.

What follows is a three-part paper. In the next section, I give a brief dissection and description of what constitutes the seven essential pieces of Modern Monetary Theory. Second, this is followed by a discussion of each of these seven parts in light of recent Institutional and post-Keynesian literature. In each of these subsections I strive to trace the arguments of the recent literature and highlight the points of agreement and disagreement. Third and finally, the paper concludes with a brief summary of findings and questions that scholars should attempt to answer in this emerging field.

\section{AN ANATOMY OF MODERN MONETARY THEORY}

What constitutes the MMT worldview? The shortlist of essential expositions on MMT would include Bell (2000; 2001), Fullwiler (2008; 2010a), Mosler (1994; 1998), Tcherneva (2006), and Wray $(1998 ; 2000 ; 2002 ; 2004)$. Perhaps the key one is L. Randall Wray's 1998 Understanding Modern Money. Drawing on his exposition,

1. In email correspondence, Anne Mayhew points out that post-Keynesians and Institutionalists agree that time is important because of fundamental uncertainty and expectations. However, Institutionalists also see time as important because of the evolution of technology and institutions. This line of reasoning has been less emphasized in the post-Keynesian tradition. So although these two schools of thought are both concerned about chronological time, they are not concerned about it for exactly the same reasons.

2. For examples of recent more popular press coverage on MMT, see Dylan Matthews article in The Washington Post on February 12, 2012. Blog references include New Economic Perspectives, Bill Mitchell, and occasionally references on Paul Krugman's New York Times blog and column and on CNBC's blog. 
as laid out in that book's table of contents, I break MMT into seven parts. These are as follows: (1) intellectual history; (2) origins of money; (3) the basic theory; (4) Godley's equation or sectoral balances approach; (5) fiscal policy; (6) monetary policy; and (7) employment policy. Each is briefly discussed below, then each is given its own subsection in the narrative that follows.

1. Intellectual History: MMT follows a long intellectual line from Adam Smith, Georg Knapp, A.M. Innes, John Maynard Keynes, Abba Lerner, Hyman Minsky, to Randall Wray and others.

2. Origins of Money: The intellectual line above is further bolstered by historical and anthropological evidence regarding the origins of money. From an MMT perspective, the history of money emphasizes the social relationships, particularly the credit relationships, which pre-date coinage. Some of these credit relationships are now expressed as money. Like Keynes, this history emphasizes the unit-ofaccount function of money.

3. Basic Theory: Taxes and bond issues do not 'finance' government spending. The government sector creates net new money whenever the combined-forthe-sake-of-argument-Treasury/Central Bank makes a purchase or transfer.

(a) Taxes are necessary to give value to money. Insufficient tax effort may cause inflation and/or depreciation of the currency in international currency markets.

(b) Bond issues do not finance government. They provide an interest-bearing asset alternative to currency holdings. Bond issues drain reserves from the banking system.

(c) The banking system as a sector does not create net new money because each loan (a bank asset) it creates as new money also requires the creation of an equal deposit (a bank liability). Banks are never reserve-constrained. They make loans and then seek reserves to meet legal and operational requirements afterwards.

4. Godley's Equation or Sectoral Balances Approach: The sum of the private sector deficit, the public sector deficit, and the current account balance will equal zero. In other words, public sector deficits make private sector surpluses (for example, profits) possible.

5. Fiscal Policy: Functional finance should be used to manage aggregate demand. This rests on Lerner's two principles of functional finance and another principle then follows from the first two.

(a) Government (Congress and the President) should increase spending and cut taxes when aggregate spending is too low. When spending is too high, government should increase taxes and cut spending.

(b) Government (the Treasury and Central Bank) should issue bonds only if it is desirable for the public to hold less money and to hold more interest-earning assets.

(c) Whenever principles (a) and (b) dictate that neither taxes should be raised nor bonds issued, the government (Congress and the President) should meet its obligations by creating money through additional government spending.

6. Monetary Policy: The Central Bank targets the overnight interest rate. It has little control over the quantity of bank-created money. Most of its actions are defensive and aimed at hitting its overnight interest rate target. The Treasury's 
changes in tax and loan accounts are viewed as part of monetary policy and their use facilitates the hitting of the target interest rate. Paying interest on reserves simplifies this process.

7. Employment Policy: To stabilize prices and to reduce unemployment, the federal government should create an Employer of Last Resort (ELR).

\section{MMT ANATOMY EXAMINED, DISSECTED, AND DIAGNOSED}

\subsection{Intellectual history}

Wray (1998: 18-37) makes a strong case that Adam Smith, Georg Knapp, and John Maynard Keynes can be connected to the same intellectual MMT thread. Smith (1776 [1937]: 312) saw that a paper currency would gain in value if it could be used to pay provincial taxes. Knapp (1924 [1973]) developed an entire State Theory of Money or Chartalist Approach. Chartal money is money imagined as a token or symbol for value. It comes from the Latin word, Charta, meaning ticket or token. For Knapp, money has value because the sovereign will accept it for payment of taxes. Keynes wrote extensively about money in his Treatise on Money and throughout much of his collected works. He explicitly agrees with Knapp. Wray (1998: 4) succinctly sums up this intellectual tradition by asserting that money is widely accepted because the "state has the power to impose and enforce tax liabilities and because it has the right to choose, "that which is necessary to pay taxes (twintopt)." It is only a small step to include A.M. Innes (1913; 1914), John Commons, Harlan McCracken, Abba Lerner, Joseph Schumpeter, and Hyman Minsky to this list as Wray (2003a; 2003b; 2004), Smithin (2000) and Whalen (2011) aptly do. This basic intellectual history appears to be as accepted by most post-Keynesians and Institutionalists as it is ignored by other economists.

\subsection{Origins of money}

Just as an exploration of the intellectual roots of MMT give it context and authority, illustrating the history of money as part of the narrative helps readers see the institutional development of credit, coinage, and fiat money as part of the historical development of property rights, markets, and exchange. Many scholars have attempted to delve into the deep origins of credit and money. These include Graeber (2011), Henry (2004; 2012), Hudson (2004), Ingham (2000; 2004), Neale (1975), Peacock (2004), Polanyi (1966; 1968), Smithin (2000), and Wray (1998; 2012). There is again widespread agreement, particularly in Graeber's book, in rejecting the view that before the rise of money there was some barter economy, the transaction costs of which were lowered by the invention of money. There simply is no evidence to support this traditional textbook myth. There is, however, growing support for the idea that credit transactions predated coinage by thousands of years. Parguez/Seccareccia (2000) would agree. Mehrling (2000), Rochon/Vernengo (2003), and Van Lear (2002) would put more emphasis on a credit approach (money is useful because it can be used to extinguish commercial and bank liabilities) and would de-emphasize a Chartal approach (money is useful because it can be used to extinguish tax liabilities). Mehrling (2000: 402) states that Wray's (1998) explanation of the historical development of money 'is speculative history at best, and would not bear much on the matter at hand, even if the history were more convincing.' Perhaps in response 
to this critique, Wray's (2012) 'Introduction to an alternative history of money' revisits this history. That article also refers to a forthcoming two-volume set from Edward Elgar, which will further contribute to the debate on this issue. In any case, the alternative history of money advocated by adherents to MMT emphasizes the Chartal or state theory of money and/or combines state and credit theories (Bell 2001; Wray 2004).

\subsection{Basic theory}

One essential notion of MMT is that a sovereign state does not use taxes and bond issues to 'finance' or fund government expenditures (Bell 2000; Bell/Wray 20022003; Forstater 1999; Knapp 1924 [1973]; Lerner 1943: 41; Mosler 1998; Tcherneva 2006; Wray 1998: 7; 2000; 2003a; 2003b; 2004). The federal government of a nation issuing its own fiat sovereign currency in a system of flexible exchange rates will create money as they make purchases and transfers funds. Government expenditures occur prior to the receipt of funds from taxes or bond issues. Taxes are gathered by government - through what Veblen might refer to as the legitimate use of coercive force - not to finance government, but to give the currency an explicit use whereby others wish to engage in production to procure it. As long as some will use this money to pay taxes, other will use money to exchange goods and services and to retire commercial and bank debts. This use of money as a medium of exchange can of course extend to the realm of international trade and finance. Despite the fact that users of the currency do not have a foreign tax liability denominated in the currency they use, the currency has value because it is accepted by others for goods and services and in payment of various other kinds of liabilities. Since a sovereign state can spend currency into being, it is impossible for the state to run out of money or to default on sovereign denominated debt. This is one of the key differences between the recent financial troubles of Greece and Spain that use the Euro, and the US, which issues debt denominated in its own dollars.

This basic theoretical approach has drawn a handful of critics. In many cases advocates of MMT have specifically, and at some points aggressively (see Lavoie 2011: 7-8 on that point), responded to these critics. For the best-known academic critiques of MMT at the level of basic theory see Febrero (2009), Gnos/Rochon (2002), Lavoie (2011), Mehrling (2000), Parguez/Seccareccia (2000), Rochon/Vernengo (2003), and Van Lear (2002). MMT has drawn both praise and criticism from non-academics on various blogs and media outlets. Given the focus of this paper on post-Keynesian and Institutionalist views on MMT, these non-academic arguments are mostly ignored for the purposes of this paper and the focus is on the published academic literature. ${ }^{3}$

Mehrling (2000) rejects Wray's (1998: 54-57) neo-chartalism. He rejects the parable about the colonial governor as too simplistic and logically equivalent to the 'goldsmith parable' of textbook infamy. He also seems to disagree with the notion that the federal government spends money into existence. This is based on his claim that it is government-issued money that 'people deposit in the bank to get the thing started' (2000: 400). Mehrling appears to be talking past his target. It could be that he is

3. Extended critiques of MMT have been made by Brett Fieberger (2012) in a working paper and by an anonymous JKH on various blogs discussing MMT. However, given the focus in this paper on published academic research by known Institutionalists and post-Keynesians, neither of these authors necessarily falls within the purview of this paper. 
thinking about money in a completely different manner. Mehrling's approach to money fundamentally differs from the two-sided balance-sheet operation used by Minsky, Wray, Bell, and others writing in this tradition. Bell (2002), for instance, is painstakingly careful when she talks about printing money. For her, printing money is an accounting maneuver. It happens when either the central bank or a commercial bank creates money endogenously to buy federal government liabilities. These liabilities serve as assets to their holders and exactly offset the initial loans. These federal government liabilities (again, assets for their holders) are virtually risk free since (1) this process of money creation is repeatable and (2) the Treasury can mint coins or bills to pay them off.

Authors writing from The Monetary Circuit (TMC) perspective share points of both agreement and disagreement with MMT. Parguez/Seccareccia's (2000) and Graziani's (1989; 2003) discussions of TMC appear to be theoretically consistent with MMT advocates in their policy opposition to austerity. They also seem to be broadly in agreement about the order in which borrowing, spending, and repayment occur. That said, they disagree about the MMT emphasis on taxes driving the value of money. For instance, some Circuitists note that Chartalism appears to be inconsistent with economic history:

(V)iable monetary systems existed during periods of economic history when taxes were quite insignificant. What matters, therefore, was not whether tax liabilities were of any significance but rather whether, largely through the legal system, the state endorsed existing banks by allowing them to issue debts on themselves. For very long historical periods state money had been quite negligible in relation to the circulation of bank liabilities. (Parguez/Seccareccia 2000: 119)

These authors would generally argue that the basic theory makes sense. However, it would make more sense in what they see as the more general analytical framework provided by the TMC approach than within MMT per se.

Gnos/Rochon's (2002) article complements the paper by Rochon/Vernengo (2003). Gnos/Rochon (2002: 45) assert that 'Wray's approach of the money-creation process is at odds with the post-Keynesian approach.' ${ }^{4}$ Rochon/Vernengo (2003) also challenge Wray and others on relying solely on a chartal approach to money. In both of these papers the authors argue - drawing on Davidson (1972) - that other institutions, including banks, can also issue paper (bank notes) that circulate as currency. People use these notes as currency because they can be used to repay debt to the bank. Rochon and Vernengo suggest that the Eurozone's existence demonstrates that the absence of any central government spending Euros into existence suggests that Chartalism does not apply there. In their defense, MMT advocates tend to be clear that their theory only applies to nation states that issue their own sovereign debt such as the United States, Canada, Australia, and Japan. In fact, MMT authors have made it clear that the structure of the Eurozone and its absence of effective state money are inherently unstable and deflationary. This insight shows the usefulness of the MMT perspective in understanding the Eurozone's troubles and in reframing the analysis to provide an alternative policy prescription to that of continued austerity.

A variety of authors - Gnos/Rochon (2002), Lavoie (2011), Rochon/Vernengo (2003), and Van Lear (2002) - are critical of the MMT penchant for conflating the

4. In contrast, Lavoie (2011: 6) says almost the opposite. 'Indeed we can certainly say that neochartalists share many common elements of monetary theory with other post-Keynesians, more precisely with the Horizontalist post-Keynesians and circuitists.' He goes on to list eight specific ways in which they agree. 
Treasury and Central Bank balance sheets into a consolidated state balance sheet. This assumption is challenged on the grounds that it is inconsistent with existing institutional arrangements in various countries, that it ignores issues of agency between the Treasury and Central Bank, and that it distorts the way in which the money creation process is described. Of the four papers, Lavoie (2011) makes the most careful use of a series of T-accounts to illuminate and explain the difference it makes if one makes a different assumption and disaggregates the two institutions.

In their defense, Wray and Bell do state that consolidating the balance sheets is a simplifying assumption and not a reflection of the actual institutional process of any particular country. These arguments are presented in Bell (2000) and Bell/Wray (2002-2003: 264-265), as well as in Bell (2002), where a disaggregated balance sheet is provided in an attempt to further clarify this point.

An author writing about the institutional process could provide a helpful contribution to this literature if this person were to use simple T-accounts of a consolidated government balance sheet and Treasury Tax and Loan (TT\&L) accounts, illustrating: (1) the creation of money (an auction of new Treasury debt purchased through a credit on a TT\&L account); (2) the destruction of money when taxes are paid; and (3) reserve drains. It would also be useful to compare how this institutionally-specific US-based process contrasts with those of other sovereign-currency-issuing countries. This might help to communicate these difficult ideas precisely and might therefore also be used for teaching purposes.

That said, some Institutionalists might still find this approach unsatisfactory. One important strand of Institutionalism's methodological basis comes from Wilbur/ Harrison's 1978 article. These authors assert that Institutionalists do not share a common theory, but do share a common form of explanation. This pattern-model of explanation requires that investigators do the following: (1) engage in participant observation; (2) perceive themes in these observations; (3) make these themes explicit; (4) compare these hypotheses or interpretations against case studies, empirical data, or additional observations; (5) build a pattern model; and (6) further fill in the pattern model as new observations come in over time. The intention is that, through intentional and guided participant-observation, an investigator is better able to understand the social relations, rules of thumb, and other institutional factors that influence the decisions made and the processes resulting within a particular institutional context.

My point here is that, although MMT attempts to be holistic and systematic, the form of explanation is not that of a pattern model of explanation. In fact, one of the claims made by the critics listed above is that MMT theorists assume the Treasury and the Central Bank have a consolidated balance sheet. This may be defended as a reasonable simplifying assumption. However, one could argue that making this assumption is inconsistent with an important strand of Institutionalism. An institutional approach more consistent with this methodology would be to study a series of actual transactions in different countries over time and then to build a pattern model of explanation.

Febrero (2009: 523) provides what might be called a sympathetic qualification of MMT - which he refers to as neo-chartalism. ${ }^{5}$ Febrero agrees that his critique avoids the central tenets of the basic theory, which he appears to accept. He also notes that the

5. Lavoie (2011: 7) notes that Fullwiler's (2010b) comment about Febrero's (2009) paper in a comment on the Econrevival blog seems excessively harsh and needlessly critical since Febrero conceded that he agreed to the basic tenets of MMT. 
policy implications remain 'essentially correct,' and that the theory provides insight into the problems inherent with the European Monetary Union. However, he asserts that the basic MMT makes three claims that 'deserve qualification.' First, he asserts that the claim 'money has value because it is accepted for tax payment at public offices' is problematic. He appeals to the current institutional set-up of the Eurozone. Given the absence of a central fiscal policy agent (like the US Congress, President, and Treasury), individual national governments in the Eurozone cannot make payments by writing checks against the European Central Bank. He rightly states (2009: 530) that 'all deficit-spending units, including national treasuries, make payments using money created by private banks.' This claim appears to be true. However, it says more about the inherent instability of the Eurozone set-up than it does about how money works in sovereign money-issuing states to which MMT does apply. So, yes, the Eurozone is a known exception. One might also point out that the Germans could have continued to use deutsche marks if they had wished. However, the state made it clear that only Euros would be accepted as payment for one's tax liability and the German people adopted the Euro immediately.

Second, Febrero wants to qualify the MMT claim (2009: 531) that 'the state controls the value of money' or its purchasing power. He argues that under certain assumptions (2009: 531) 'the nominal wage becomes predetermined ... [i]n other words, there is no margin for nominal wage bargaining.' This stylized fact is at odds with the post-Keynesian idea that banks create money in part to finance wages. He further asserts that this means (2009: 531) 'changes in money supply follow changes in prices and nominal wages, and not vice versa.' In this case, accommodative lending by banks can increase prices. This outcome undermines the Chartalist desire to create price stability as well as its claim that the state can determine the purchasing power of money. However, Febrero arrives at this conclusion through changing the assumptions under which the process of wage determination is allowed to operate. Thus, the theoretical result is not particularly surprising or broadly applicable.

Third, Febrero's final claim is the most substantive and difficult to summarize succinctly. Simply stated, he wants to clarify the statement that 'bank money is a leverage of fiat money.' He is right in saying that there is disagreement among post-Keynesians regarding what this means. He relies on Lavoie (1999: 370) and Parguez/Seccareccia (2000: 120) to argue that post-Keynesians agree that state money is fully endogenous and that the creation of bank money is not constrained by state money. But Febrero does raise a pair of provocative questions: What precisely is the role of state money within the endogenous money supply process? Is there any limit to endogenous money creation by banks, other than the demand for credit? I quote Febrero at length here to convey the importance of this question:

One is tempted to conclude that banks have to collect state money (or public debt, i.e., Treasury bills and bonds) first (in a logical sense), and then they can make loans and create deposits later. In this interpretation, state money should not be understood as reserves in the textbook conventional view, but as a sort of bank capital that should be used when a bank has to make a payment either to another bank or when its clients have to settle taxes. If this is correct, then there are, at least, two snags: (1) if private banks 'move forward in step' to use Keynes's (1930 [1976], p. 23) words, there is no limit for the creation of bank money; and (2) if a particular bank creates deposits beyond a prudent threshold (given by reserves plus bank capital), the central bank will initially help this bank and then penalize it. (Febrero 2009: 533) 
Wray (1998: 111-115; 2004: 259) addresses the question of how state and bank money are related, but his discussion does not, at least in these two places, elucidate definitive financial limits to bank money creation. Bell (2001), in her discussion of money hierarchies, also provides background that can be used to inform this question, but her arguments do not fully satisfy this reader. In short, Febrero appears to raise a good question about the relationship between state money and bank money and the limits (if any) to endogenous money creation by the banking system in this framework. It is an area ripe for further research. There appear to be limits both to how much a government can spend and how much a bank can lend. However, these limits are not the limits one learns from a mainstream economics perspective or from available textbooks. Instead they are demand-determined.

In sum, on this third piece of MMT, post-Keynesian and Institutional scholars have disagreed about (1) the degree to which Chartalism is applicable to the contemporary financial system, (2) the usefulness of using consolidated or disaggregated balance sheets to model the money creation process, and (3) the limits, if any, to the endogenous money creation process of commercial banks. MMT scholars have responded to or anticipated these criticisms. Individual post-Keynesians and Institutionalists will have to decide whether these issues are resolved or whether they remain live issues worthy of further research and argument.

\subsection{Godley's equation or sectoral balances}

MMTers employ a sectoral balances approach mostly associated with Wynne Godley (Godley 1999; Godley/Cripps 1983) to think about expenditures in the economy. In his book, Wray (1998: 83) makes reference to this sectoral balances approach, as does Fullwiler (2009). It follows directly from commonly-used equations of national income accounting. Because this sectoral balance equation has become fairly wellknown since the advent of the financial crisis, as several researchers have attempted to interpret the evolution of the crisis with the help of this equation, I simply present it without showing how to derive it:

$$
(I-S)+(G-T)+(X-M+N F Y)=0
$$

where $I$ is private investment, $S$ is domestic private saving, $G$ is government expenditures, $T$ is taxes net of transfer payments, $X$ is exports, $M$ is imports and $N F Y$ is net foreign income. The equation is interpreted as saying that the sum of the private sector deficit $(I-S)$, the public sector deficit $(G-T)$, and the current account balance $(X-M+$ $N F Y$ ) will equal zero. Another interpretation is that there can be no private financial saving without a public sector deficit, assuming the external sector is in balance.

Although most Institutionalists may agree with this logical framework for thinking about the flow of funds in this manner, some might point out that the system itself remains agnostic on the issue of agency, a recurrent theme in institutionalist work. Since the expenditure flows are interdependent, which sector necessarily causes changes in the other sectors remains unclear. Typically, MMT advocates assume that it is the public sector deficit (or surplus) that drives changes in the private and foreign sectors. However, there is nothing in the logic of the equations themselves that requires this particular assumption of agency by the federal government.

The only substantive published criticism or at least miscommunication of this approach comes from Steve Keen (2009; 2012). In his 2009 chapter, Keen 
dynamically models the TMC approach and seems to reach broadly similar conclusions to MMT. However, he does argue that (emphasis his) 'aggregate demand is income plus the change in debt, and this is expended on both goods and services and financial assets' (Keen 2012: 3-4). This is at odds with Godley's equation above that presumes aggregate demand $(C+I+\mathbf{G}+X n)$ is synonymous with income as defined by the national income and product accounts (NIPA). Keen seems to be including the purchases of 'financial assets' into his definition of aggregate demand. While such purchases may be important to consider, they do not fall into the definition of GDP as defined by the NIPA. This appears to be an issue in need of further research and clarification.

\subsection{Fiscal policy}

In terms of MMT fiscal policy, Abba Lerner's (1943 and 1947) functional finance stands as an essential part of MMT, although it predates its full development by a few decades (Forstater 1999). Functional finance basically asserts that the fiscal position of a nation state should be operated according to the needs of the overall economy, not by the fetish of balanced budgets at all times or over some particular span of time. During a recession, a federal government should run a deficit. In a period of excessive aggregate demand, the federal government should tend towards a surplus. Further, bonds should only be issued to take money out of the hands of the public to be replaced with bonds. If neither taxes nor bond issues should be appropriately raised, government spending should be done through the creation of new money.

Mehrling finds the ideas of Knapp, Lerner, and Keynes as no longer applying to a 'modern financially sophisticated world where private markets are apparently in ascendance' (2000: 398). Given the frequency that these authors continue to get cited in the Journal of Post Keynesian Economics (JPKE), the Journal of Economic Issues (JEI), and other related journals, this criticism, if taken seriously, must be directed at many post-Keynesians and Institutionalists and not just at MMT. The main disagreements among post-Keynesians and Institutionalists over fiscal policy tend to be over issues related to an employer of last resort (ELR). That issue is taken up in section 3.7 below.

\subsection{Monetary policy}

The main goal of monetary policy is to establish the overnight interest-rate target and to hit this target. This will require that the Central Bank works with the Treasury to actively manage its tax and loan accounts so that reserves become neither too abundant nor too scarce, either of which can obstruct the central bank's ability to hit its target. Bond sales, like federal taxes, serve as ways to drain reserves from the banking system. Bond purchases and government spending add reserves to the banking system. Forstater/ Mosler (2005: 538-539) describe how this works:

When the government realizes a budget deficit, there is a net reserve add to the banking system. That is, government deficit spending results in net credits to member bank reserve accounts. If these net credits lead to excess reserve positions, overnight interest rates will be bid down by the member banks with excess reserves to the interest rate paid on reserves by the central bank.... If the central bank has a positive target for the overnight lending rate, either the central bank must pay interest on reserves or otherwise provide an interest-bearing alternative to non-interest-bearing reserve accounts. This is typically done by offering 
securities for sale in the open market to drain the excess reserves. Central Bank officials and traders recognize this as 'offsetting operating factors,' since the sales are intended to offset the impact of the likes of fiscal policy, float, and so forth on reserves that would cause the Fed funds rate to move away from the Fed's target rate.

Without action by the Central Bank, the primary problem or penalty caused by a government budget deficit is not some threat of default or a bounced check by the federal government. Instead the problem is that the overnight interest rate will fall to zero. This result is exactly the opposite of mainstream theorists and textbooks that claim that government borrowing increases short-term interest rates and 'crowds out' private investment.

Although this approach to monetary policy is a sharp contrast to mainstream views, there has been little controversy in the PKI literature to challenge this approach independently of the critiques on the basic theory already discussed in the previous section. In fact, Forstater and Mosler's views are echoed by Fullwiler (2006: 521), who makes it clear that 'the Fed can set its overnight interest rate at any level - even zero.' It is also worth noting that, beginning 1 October 2008, the Federal Reserve District Banks pay interest on reserves held at the Fed. This has reduced the need to drain reserves by selling bonds to maintain a positive interest rate since the federal funds rate can fall no further than the interest rate on reserves. In any case, from the MMT perspective, the short-term interest rate is a policy decision determined by central bank authorities. External market pressures do not determine a sovereign-currency-issuing nation's interest rate.

\subsection{Employment policy}

Post-Keynesians and Institutionalists have for decades asserted that macroeconomic policymakers should act to stabilize prices and promote full employment. One important way to pursue these objectives is for the federal government to provide bufferstock employment (BSE), job guarantee (JG), or an employer of last resort (ELR) program. An ELR, funded at the federal level, would simply stand ready to hire all willing, able, and available workers at or above the minimum wage. Examples of these forms of public service employment include Forstater $(1998 ; 1999 ; 2001$; 2002), Gordon (1997), Kregel (1999), Lerner (1943), Minsky (1986), Mitchell (1998), Mitchell/Mosler (2005), Mitchell/Wray (2005), Mosler (1998), Tcherneva/ Wray (2005), and Wray (1998), among others. Ironically Mehrling (2000: 401), who is such a fierce critic of MMT's Chartalist foundation, is not a critic of ELR. In fact, he refers to ELR as 'a proposal that may well be worth trying in some form.'

The critics of ELR have also been vociferous about not only the details of an ELR but also about its mere existence. Paul Davidson has been a leading voice in the postKeynesian tradition. However, Tcherneva and Wray (2005: 7) assert that Davidson refers to ELR variously as, 'communism,' 'fascism,' and 'slavery.' Sawyer's 2003 Journal of Economic Issues article was primarily about ELR, pointing out that insufficient aggregate demand is only one cause of unemployment. Other structural issues 'notably the lack of productive capacity, inflation barriers, and balance of trade constraints, as well as political and intellectual constraints' (2003: 904) are not ameliorated by an ELR. Sawyer, like Aspromourgos (2000) and Lopez-Gallardo (2000) before him, argues that price stability would not be assured by an ELR system. Sawyer's article spurred sharp responses from Mitchell/Wray (2005) as well as from Forstater (2005), and Sawyer (2005) provides a thoughtful reply to his critics. 
Lopez-Gallardo (2000: 549-552) would add that solving unemployment through an ELR is likely to increase a nation's trade deficit. Seccareccia (2004: 34) concurred with Sawyer, stating that if the ELR wage were set high enough, a 'wage-wage' spiral could be induced. Alternatively, an ELR wage set too low could exacerbate already problematic levels of income inequality and thereby erode effective demand.

Like other articles on MMT, the work of Kadmos and O'Hara (2000) has inspired comment from J.E. King (2001) and a response to King from O'Hara and Kadmos (2001). In the original article, Kadmos and O'Hara make a supportive critique of MMT with respect to Chartalism and ELR. They agree that the Chartalist position is consistent with the actual institutional practices of modern states as well as the intellectual tradition of scholars for centuries. Their critique rests on whether an ELR is the best way to use the funds that are now available as a result of this new taxesdrive-money (TDM from now on) understanding of how the world works. They argue that Wray's ELR approach and Lerner's functional finance approach are using different definitions of unemployment. They assert that functional finance can only be used to eliminate what is today referred to as frictional unemployment. In contrast, they argue, Wray hopes to eliminate all unemployed workers except those who are unable or unwilling to work. This includes both cyclical and structural unemployment. Kadmos and O'Hara find this problematic since Wray relies on Lerner's functional finance to make the TDM argument. Rather than using an ELR, Kadmos and O'Hara advocate for large public sector investments. They argue, particularly in the case of Australia, that this would 'require the building of knowledge, communications, infrastructural, social and corporate network capitals' (Kadmos/O'Hara 2000: 16). It is these kinds of human and social capital - and not consumption spending alone - that are more likely to address the problems of long-term structural unemployment.

King extends and/or refines the critique of Kadmos/O'Hara in four areas. First, King argues that the connection between the taxes-drive-money (TDM) approach and ELR are weaker than the original authors imply. He does not reject TDM, but argues that the ELR is more influential in the literature historically and that the ELR can be defended without recourse to MMT. Second, King critiques Wray (1998) and Kadmos/O'Hara (2000) by pointing out that the advantages of the low cost (relative to GDP or to federal expenditures) of an ELR are at odds with asserting that it will serve as an adequate stimulus. If it is only a small part of GDP, it simply cannot serve as a significant stimulus. Therefore there is no reason to believe that it constitutes a 'powerful built-in stabilizer' (Kadmos/O'Hara 2000: 7). Third, there are two political problems with ELR. Although Wray's version of ELR appears to be free of compulsory labor, Gordon (1997) and Mitchell/Watts (1997) suggest that ELR could in practice become a 'work-for-the-dole scheme.' Many on the left would find this repugnant.

Similarly, King raises an important question. Would an ELR necessarily undermine union bargaining and restrain their ability to impose cost-push inflation? King draws on Minsky to assert that union power would be reined in by the knowledge that if well-paid jobs in the private sector were lost as a result of "excessive" pay demand, the alternative for union members would be low wage employment in the public sector' (King 2001: 3). This sentiment echoes similar concerns raised by Seccareccia (2004) and also Palley (2001: 3) that ELR jobs may take away, at low wages, well-paid jobs from unionized government workers, thus in the end leading to lower aggregate demand. Wray (1998: 145) clearly disagrees, and argues that ELR would be neutral on union power. Fourth and finally, King suggests that there are at least three alternatives to the low-wage ELR approach advocated by ELR. First he suggests that 
Swedish-inspired active labor market policies (ALMP) may be more appropriate. These would include: (1) a right to education and training to better confront the needs created by structural unemployment; and (2) pay higher wages - up to 90 percent of their previous post-tax income - to more strongly offset the income-reducing effects of a cyclical downturn. Secondly, King would suggest that another more politically viable option favored by many on the left would be a Basic Income Guarantee (BIG). His third and final solution is to combine these two policies into a radical position: a high-wage ALMP for those who work and a generous BIG to those who do not. In the end he sees all three of these as impractical, and settles on an ELR as a 'last resort.'

\section{CONCLUSIONS AND AREAS FOR FUTURE RESEARCH}

So, in conclusion, are post-Keynesians and Institutionalists converging on a shared approach to MMT? It depends. At least four important sets of questions remain unanswered. They include the following:

- Can we agree on a common definition of money? Bell (2001: 150-151) suggests, à la Innes (1913: 392), that money is credit. It represents a social relation that is expressed as a two-sided balance sheet operation. The creation of money requires that one accepts another's debt as an asset.

- What exactly is the role of state money within the endogenous money supply process? Is there any limit to endogenous money creation by banks, other than the demand for credit?

- Is the use of a consolidated Treasury-Central Bank balance sheet the best or only way to illustrate the money creation process generated by federal government spending and consistent with MMT? Would institutional research using methods suggested by Wilbur/Harrison (1978) better illuminate the contextually-specific institutional processes that facilitate and constrain the creation of money through federal government spending in different countries and with different institutional arrangements?

- Would the implementation of an ELR necessarily undermine union bargaining and thereby reduce inflation? Would well-paid government employees be replaced by lower-wage ELR recipients? In the process of reining in inflation, would wages be reduced, thereby also reducing aggregate demand? Would an ELR rein in or encourage cost-push inflation sparked by unions - and workers more generally - pressing for higher wages?

Despite these unresolved sets of questions, post-Keynesians and Institutionalists do share an intellectual history, a set of common core theoretical ideas, and a number of scholars who have written in both traditions. It is out of these traditions, imperfectly applied, that MMT has developed. Like other ideas within the tradition, there are heated intellectual disagreements among scholars. MMT is not, yet, a settled framework for theorizing and making policy. However, it is the post-Keynesians and Institutionalists or PKIs - who are making the primary arguments in favor of and in opposition to MMT. And these arguments are being made primarily on the pages of leading postKeynesian, Institutionalist, and other leading heterodox journals, including the Journal of Post Keynesian Economics, the Journal of Economic Issues, the International Journal of Political Economy, the Eastern Economic Journal, and the Journal of Economic and Social Policy. The European Journal of Economics and Economic Policy is a welcome 
addition to the conversation. So, do all post-Keynesians, Institutionalists and PKIs agree on all seven components of MMT? No. Has MMT become an important part of the conversation about how they think about macroeconomics and macroeconomic policy? Absolutely.

MMT can be challenged, debated, and refined. However, given its intellectual roots, implications for public policy, increasing presence in academic journals, mainstream press, and blogged debates, those who are thinking, teaching, and writing in the PKI tradition can no longer ignore it. MMT has become an essential, albeit controversial, part of that conversation and is deserving of the increasing attention and respect that it attracts.

\section{REFERENCES}

Aspromourgos, T. (2000): Is an employer-of-last-resort policy sustainable? A review article, in: Review of Political Economy, 12(2), 141-155.

Bell, S. (2000): Do taxes and bonds finance government spending?, in: Journal of Economic Issues, 34(3), 603-620.

Bell, S. (2001): The role of the state and the hierarchy of money, in: Cambridge Journal of Economics, 25(2), 149-163.

Bell, S. (2002): A reply to 'A political economic commentary on government finance and monetary policy,' in: Journal of Economic Issues, 36(1), 186-189.

Bell, S., Wray, L.R. (2002-2003): Fiscal effects on reserves and the independence of the Fed, in: Journal of Post Keynesian Economics, 25(2), 263-271.

Davidson, P. (1972): Money and the Real World, London: Macmillan.

Febrero, E. (2009): Three difficulties with neo-Chartalism, in: Journal of Post Keynesian Economics, 31(3), 523-541.

Fieberger, B. (2012): Modern Monetary Theory: a debate, Political Economy Research Institute Working Paper Series No. 279, University of Massachusetts-Amherst.

Forstater, M. (1998): Flexible full employment: structural implications of discretionary public sector employment, in: Journal of Economic Issues, 32(2), 557-563.

Forstater, M. (1999): Functional finance and full employment: lessons from Lerner for today, in: Journal of Economic Issues, 33(2), 475-482.

Forstater, M. (2001): An Institutionalist post Keynesian methodology of economic policy with an application to full employment, CFEPS Working Paper No. 18, URL: http://www.cfeps. org/pubs/wp/wp18.html.

Forstater, M. (2002): 'Jobs for all': another dream of the Rev. Dr. Martin Luther King, Jr., in: Forum for Social Economics, 31(2), 45-53.

Forstater, M. (2005): Reply to Malcolm Sawyer, in: Journal of Economic Issues, 39(1), 245-255.

Forstater, M., Mosler, W. (2005): The natural rate of interest is zero, in: Journal of Economic Issues, 39(2), 539-542.

Fullwiler, Scott (2006): Setting interest rates in the modern monetary eras, in: Journal of Post Keynesian Economics, 28(3), 495-525.

Fullwiler, S.T. (2008): Modern central bank operations: the general principles, SSRN, URL: http://ssrn.com/abstract=1658232 or http://dx.doi.org/10.2139/ssrn.1658232.

Fullwiler, Scott (2009): The sector financial balances model of aggregate demand - revised, 26 July, URL: http://neweconomicperspectives.org/2009/07/sector-financial-balancesmodel-of_26.html.

Fullwiler, S.T. (2010a): Modern monetary theory - a primer on the operational realities of the monetary system, URL: http://ssrn.com/abstract=1723198 or http://dx.doi.org/10.2139/ ssrn. 1723198.

Fullwiler, Scott (2010b), Re-reviewing Chartalism/Neochartalism, comment, July 8, URL: http://econrevival.blogspot.com/2010/07/re-reviewing-chartalsim-neo-chartalism.html. 
Gnos, C., Rochon, L.-P. (2002): Money creation and the state: a critical assessment of Chartalism, in: International Journal of Political Economy, 32(3), 41-57.

Godley, W. (1999): Seven Unsustainable Processes: Strategic Analysis, Annandale-on-Hudson, NY: The Levy Economics Institute.

Godley, W., Cripps, T.F. (1983): Macroeconomics, Oxford: Fontana and Oxford University Press.

Gordon, W. (1997): Job assurance - the job guarantee revisited, in: Journal of Economic Issues, 31(3), 826-834.

Graeber, David (2011): Debt: The First 5000 Years, Brooklyn, NY: Melville House Publishing.

Graziani, A. (1989): The theory of the monetary circuit, in: Thames Papers in Political Economy, 1-26. Reprinted in Musella, M., Panico, C. (eds) (1995): The Money Supply in the Economic Process, Aldershot: Edward Elgar.

Graziani, A. (2003): The Monetary Theory of Production, Cambridge, UK: Cambridge University Press.

Henry, J.F. (2004): The social origins of money: the case of Egypt, in: Wray, L.R. (ed.), Credit and State Theories of Money, Cheltenham, UK and Northampton, MA, USA: Edward Elgar, 79-98.

Henry, J.F. (2012): The Veblenian predator and financial crises: a view from 1923, presented at The Association for Evolutionary Economics (AFEE), Chicago, IL, January.

Hudson, M. (2004): The archaeology of money: debt versus barter theories of money's origins, in: Wray, L.R. (ed.), Credit and State Theories of Money, Cheltenham, UK and Northampton, MA, USA: Edward Elgar, 99-127.

Ingham, G. (2000): Babylonian madness: on the historical and sociological origins of money, in: Smithin, J. (ed.), What is Money?, London: Routledge, 16-41.

Ingham, G. (2004): The Nature of Money, Cambridge: Polity Press.

Innes, A.M. (1913): What is money?, in: Banking Law Journal, May, 377-408.

Innes, A.M. (1914): The credit theory of money, in: Banking Law Journal, January, 151-168.

Kadmos, G., O'Hara, P.A. (2000): The taxes-drive-money and employer of last resort approach to government policy, in: Journal of Economic and Social Policy, 5(1), 1-18.

Keen, S. (2009): The dynamics of the monetary circuit, in: Rossi, S., Ponsot, J.F. (eds), The Political Economy of Monetary Circuits: Tradition and Change, London: Palgrave Macmillan, 161-187.

Keen, S. (2012): Instability in financial markets: sources and remedies, INET Conference, Berlin, unpublished manuscript, URL: http://www.debtdeflation.com/blogs.

Keynes, J.M. (1930 [1976]): A Treatise on Money, Volumes I and II, New York: Harcourt, Brace \& Company.

King, J.E. (2001): The last resort? Some critical reflections on ELR, in: Journal of Economic and Social Policy, 5(2), 72-76.

Knapp, G.F. (1924 [1973]): The State Theory of Money, Clifton: Augustus M. Kelley.

Kregel, J.A. (1999): Price stability and full employment as complements in a new Europe, in: Davidson, P., Kregel, Jan (eds): Full Employment and Price Stability in a Global Economy, Cheltenham, UK: Edward Elgar, 178-194.

Lavoie, M. (1999): Book review: Understanding Modern Money, in: Eastern Economic Journal, 25(3), 370-372.

Lavoie, M. (2011): The monetary and fiscal nexus of neo-Chartalism: a friendly critical look, IMK Berlin conference paper, URL: http://www.boeckler.de/pdf/v_2011_10_27_lavoie.pdf.

Lerner, A.P. (1943): Functional finance and the federal debt, in: Social Research, 10, 38-51.

Lerner, A.P. (1947): Money as a creature of the state, in: The American Economic Review, 37, 312-317.

Lopez-Gallardo, J. (2000): Budget deficit and full employment, in Journal of Post Keynesian Economics, 22(4), 549-563.

Matthews, D. (2012): Modern Monetary Theory, an unconventional take on economic strategy, in: The Washington Post, February 12, URL: http://www.washingtonpost.com/business/ modern-monetary-theory-is-an-unconventional-take-on-economic-strategy/2012/02/15/ gIQAR8uPMR_story.html.

Mehrling, P. (2000): Modern money: fiat or credit?, in: Journal of Post Keynesian Economics, 22(3), 397-406. 
Minsky, H. (1986): Stabilizing an Unstable Economy, New Haven: Yale University Press.

Mitchell, W. (1998): The buffer stock employment model, in: Journal of Economic Issues, 32(2), $547-555$.

Mitchell, W., Mosler, W. (2005): Essential elements of a modern monetary economy with applications to social security privatisation and the intergenerational debate, Centre of Full Employment and Equity (CofFEE) of the University of Newcastle Working Paper, no. 05-01.

Mitchell, W., Watts, M. (1997): The path to full employment, in: Australian Economic Review, 31(4), 436-444.

Mitchell, W., Wray, L.R. (2005): In defense of employer of last resort: a response to Malcolm Sawyer, in: Journal of Economic Issues, 39(1), 235-244.

Mosler, W. (1994): Soft Currency Economics, West Palm Beach, URL: http://moslereconomics. com/mandatory-readings/soft-currency-economics/.

Mosler, W. (1998): Full employment and price stability, in: Journal of Post Keynesian Economics, 20(2), 167-182.

Neale, W.C. (1975): Monies in Societies, San Francisco: Chandler and Sharp.

O'Hara, Phillip Anthony and Kadmos, George Anthony (2001): A reply to King: employer of last resort and taxes-drive-money revisited, in: Journal of Economic and Social Policy, 5(2), article 6, URL: http://epubs.scu.edu.au/jesp/vol5/iss2/6/.

Palley, T.I. (2001): Government as employer of last resort: can it work?, in: Industrial Relations Research Association, 53rd Annual Proceedings, 269-274, URL: http://www.thomaspalley. com/docs/articles/macro_policy/government_employer.pdf.

Parguez, A., Seccareccia, M. (2000): The credit theory of money: the monetary circuit approach, in: Smithin, J. (ed.), What is Money?, London: Routledge, 101-123.

Peacock, M. (2004): State, money, catallaxy: underlaboring for a chartalist theory of money, in: Journal of Post Keynesian Economics, 26(2), 205-225.

Polanyi, K. (1966): Dahomey and the Slave Trade: An Analysis of an Archaic Economy, Seattle, WA: University of Washington Press.

Polanyi, K. (1968): Primitive, Archaic and Modern Economics: Essays of Karl Polanyi, Dalton, G. (ed.), Garden City, NY: Anchor Books.

Rochon, P., Vernengo, M.V. (2003): State money and the real world: or chartalism and its discontents, in: Journal of Post Keynesian Economics, 26(1), 57-67.

Sawyer, M. (2003): Employer of last resort: could it deliver full employment and price stability?, in: Journal of Economic Issues, 37(4), 881-907.

Sawyer, M. (2005): Employer of last resort: a response to my critics, in: Journal of Economic Issues, 39(1), 256-264.

Seccareccia, M. (2004): What type of full employment? A critical evaluation of government as employer of last resort policy proposal, Investigacion Economica, 63(247), 15-43.

Smith, A. (1776 [1937]): An Inquiry into the Wealth of Nations, The Cannan Edition, New York: Modern Library.

Smithin, J. (ed.) (2000): What is Money?, London: Routledge International Studies in Money and Banking.

Tcherneva, P.R. (2006): Chartalism and the tax-driven approach to money, in: Arestis, P., Sawyer, M. (eds), Handbook of Alternative Monetary Economics, Northampton, MA: Edward Elgar, 69-86.

Tcherneva, P., Wray, L.R. (2005): Employer of last resort program: a case study of Argentina's Jefes de Hogar program, Center for Full Employment and Price Stability of the University of Missouri - Kansas City Working Paper, No. 41.

Van Lear, W. (2002): A political economic commentary on government finance and monetary policy, in: Journal of Economic Issues, 36(1), 183-185.

Whalen, C. (ed.) (2011): Financial Instability and Economic Security after the Great Recession, Cheltenham, UK and Northampton, MA, USA: Edward Elgar.

Wilbur, C.K., Harrison, R.S. (1978): The methodological basis of Institutional economics: pattern model, storytelling, and holism, Journal of Economic Issues, 12(1), 61-89.

Wray, L.R. (1998): Understanding Modern Money: The Key to Full Employment and Price Stability, Northampton, MA: Edward Elgar. 
60 European Journal of Economics and Economic Policies: Intervention, Vol. 10 No. 1

Wray, L.R. (2000): Modern money, in: Smithin, J. (ed.), What is Money?, London: Routledge, $42-66$

Wray, L.R. (2002): State money, in: International Journal of Political Economy, 32(3), 23-40.

Wray, L.R. (2003a): Functional finance and US government budget surpluses, in: Nell, E., Forstater, M. (eds), Reinventing Functional Finance, Cheltenham, UK and Northampton, MA, USA: Edward Elgar, 141-59.

Wray, L.R. (2003b): The neo-chartalist approach to money, in: Bell, S., Nell, E. (eds), The State, the Market and the Euro, Cheltenham, UK and Northampton, MA, USA: Edward Elgar, 89110.

Wray, L.R. (ed.) (2004): Credit and State Theories of Money: The Contributions of A. Mitchell Innes, Cheltenham, UK: Edward Elgar.

Wray, L.R. (2012): Introduction to an Alternative History of Money, in: Levy Institute Working Paper No. 717, Annandale-on-Hudson, NY: The Levy Economics Institute. 